\title{
Phylogenetic Analysis of the pPT23A Plasmid Family of Pseudomonas syringae ${ }^{\nabla}$
}

\author{
Zhonghua Ma, ${ }^{1,2} \dagger$ James J. Smith, ${ }^{3,4}$ Youfu Zhao, ${ }^{1,2} \ddagger$ Robert W. Jackson, ${ }^{5} \S$ Dawn L. Arnold, ${ }^{6}$ \\ Jesús Murillo, ${ }^{7}$ and George W. Sundin ${ }^{1,2 *}$ \\ Department of Plant Pathology, ${ }^{1}$ Center for Microbial Ecology, ${ }^{2}$ Department of Entomology, ${ }^{3}$ and Lyman Briggs School of Science, ${ }^{4}$ \\ Michigan State University, East Lansing, Michigan; Department of Biology and Biochemistry, University of Bath, Bath, \\ United Kingdom ${ }^{5}$; Centre for Research in Plant Science, University of the West of England, Bristol, United Kingdom ${ }^{6}$; and \\ Departamento de Produccion Agraria, Universidad Publica de Navarra, Pamplona, Spain ${ }^{7}$
}

Received 11 August 2006/Accepted 7 November 2006

\begin{abstract}
The pPT23A plasmid family of Pseudomonas syringae contains members that contribute to the ecological and pathogenic fitness of their $P$. syringae hosts. In an effort to understand the evolution of these plasmids and their hosts, we undertook a comparative analysis of the phylogeny of plasmid genes and that of conserved chromosomal genes from $P$. syringae. In total, comparative sequence and phylogenetic analyses were done utilizing 47 pPT23A family plasmids (PFPs) from 16 pathovars belonging to six genomospecies. Our results showed that the plasmid replication gene $(\operatorname{rep} A)$, the only gene currently known to be distributed among all the PFPs, had a phylogeny that was distinct from that of the $P$. syringae hosts of these plasmids and from those of other individual genes on PFPs. The phylogenies of two housekeeping chromosomal genes, those for DNA gyrase B subunit $(g y r B)$ and primary sigma factor $(r p o D)$, however, were strongly associated with genomospecies of $P$. syringae. Based on the results from this study, we conclude that the pPT23A plasmid family represents a dynamic genome that is mobile among $P$. syringae pathovars.
\end{abstract}

Pseudomonas syringae is a fluorescent plant-pathogenic pseudomonad clustering within rRNA similarity group I of the genus Pseudomonas (23). The species is subdivided into at least 51 pathovars, which are mostly described on the basis of plant host range (52). Thus, although the $P$. syringae species as a whole causes plant diseases on a multitude of hosts, individual $P$. syringae pathovars typically have a limited host range of one to a few plant species. A comprehensive genetic analysis has indicated the existence of nine discrete genomospecies on the basis of total DNA-DNA homology and ribotyping (12). Individual genomospecies had DNA relatedness values between 66 and $100 \%$ with $\Delta T_{m}$ values of 0.0 to $4.5^{\circ} \mathrm{C}(12)$; these values are consistent with those used by others in delineating bacterial species $(5,27)$. Thus, the pathogen $P$. syringae is genetically diverse, presumably due to the adaptation of individual pathovars to their respective host plant environments.

Initial characterization of plasmids within the $P$. syringae species revealed that individual plasmids from different $P$. syringae pathovars could share extensive sequence homology (24, 47). Further understanding of the interpathovar relationship of $P$. syringae plasmids occurred following the subcloning of replication sequences from the $80-\mathrm{kb}$ plasmid pOSU900 of $P$. syringae pv. syringae (19). A probe constructed from the

\footnotetext{
* Corresponding author. Mailing address: Michigan State University, Department of Plant Pathology, 103 CIPS, East Lansing, MI 48824. Phone: (517) 355-4573. Fax: (517) 353-5598. E-mail: sundin @msu.edu.

$\dagger$ Present address: Biotechnology Institute, Zhejiang University, Hangzhou 310029, People's Republic of China.

$\$$ Present address: Department of Crop Sciences, University of Illinois, 1201 W. Gregory Ave., Urbana, IL 61801.

$\S$ Present address: School of Biological Sciences, University of Reading, Whiteknights, Reading RG6 6AJ, United Kingdom.

${ }^{\nabla}$ Published ahead of print on 17 November 2006.
}

pOSU900 replication sequences was later shown to hybridize to several native plasmids ( 50 to $80 \mathrm{~kb}$ ) isolated from a distinct population of $P$. syringae pv. syringae $(36,37)$. Murillo and Keen (20) cloned the replication sequences from the $100-\mathrm{kb}$ plasmid pPT23A of $P$. syringae pv. tomato PT23 and demonstrated that these sequences hybridized to additional plasmids within strain PT23 and to plasmids of a variety of sizes from a diversity of $P$. syringae pathovars. This important work was then followed by the sequencing of the replication gene (rep $A$ ) from pPT23A (13) and the definition of the pPT23A plasmid family as a group comprised of plasmids mostly ranging from approximately 35 to $100 \mathrm{~kb}$ (with a few exceptions) that are believed to have originated from a common ancestor because they share a gene $($ rep $A)$ that encodes an essential replication protein (33). To date, pPT23A family plasmids (PFPs) have been confirmed in strains from 19 pathovars from four genomospecies $(32,41,54)$; it should be noted that PFPs have been detected in all pathovars examined; thus, the current pathovar distribution is limited only in that additional pathovars have not been tested. The pPT23A plasmid family also appears to be unique in that a number of $P$. syringae strains harbor two to as many as six PFPs (32). While conventional wisdom would suggest that plasmids sharing highly similar replication sequences would not be capable of inhabiting the same bacterial cell, PFPs overcome this potential problem by an as-yet-unknown mechanism.

Genomic analyses have provided glimpses of the gene content of PFPs and similarities and differences among PFPs from various $P$. syringae pathovars. Eight complete PFP sequences are currently known including $\mathrm{pFKN}$ from $P$. syringae $\mathrm{pv}$. maculicola (26), pDC3000A and pDC3000B from $P$. syringae pv. tomato (6), pPSR1 from $P$. syringae pv. syringae (40), pMA4326A and pPMA4326B from $P$. syringae pv. maculicola 


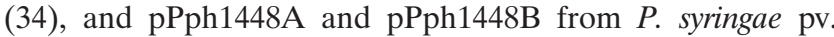
phaseolicola (17). These sequencing studies, combined with the results of many previous studies, indicate that genes encoding effector proteins of importance to host-pathogen interactions, other determinants involved in virulence and epiphytic fitness of $P$. syringae, determinants increasing strain survival on plants sprayed with agricultural bactericides, genes encoding plasmid replicative and transfer functions, and mobile genetic elements have been identified on PFPs from various pathovars of $P$. syringae (reviewed in reference 46). Notable examples include the avrPph locus of pAV511 from $P$. syringae pv. phaseolicola, which contains two open reading frames that confer avirulence on bean cultivars carrying the $R 1$ resistance gene and contribute to virulence on other bean cultivars and on soybean (44), the biosynthetic gene cluster for the phytotoxin coronatine on $\mathrm{pPG} 4180 \mathrm{~A}$ from $P$. syringae $\mathrm{pv}$. glycinea (1), and the $r u l A B$ locus on pPSR1 from $P$. syringae pv. syringae, which encodes tolerance to UV radiation $(38,39)$.

An understanding of the distribution of particular PFP-carried genes within and among pathovars should provide important clues in the evolutionary development of these plasmids. Determinants such as $\operatorname{rul} A B$ and $i a a L$, which are thought to be important to the survival and growth of $P$. syringae in the leaf surface or phyllosphere environment, are found on PFPs from at least 17 to 20 pathovars $(14,41)$. In contrast, genes encoding effectors, such as avrPpiA1 and avrRPM1, are limited in distribution to only a few pathovars (54). A recent comparative genomic approach examining 31 PFPs revealed that the plasmids could be subdivided into major groups based on the conjugative transfer (type IV secretion) system encoded (54). Two distinct transfer systems were found, a type IVA (VirBVirD4) system and a type IVB (Tra) system, and these systems were detected in 27 of 31 PFPs examined (54).

Our long-term goal is to understand the molecular evolution of the pPT23A plasmid family, with one goal being to catalog the acquisition of genes by PFPs, track the reassortment of these genes at several levels within the $P$. syringae species (for example strains within populations, pathovars, and genomospecies), and identify and determine the functional significance of novel adapted alleles (mediated through base alterations). Here, we performed a comprehensive comparative sequence and phylogenetic analysis of the pPT23A plasmid family. Our experiments were designed to answer the following questions: (i) whether the pPT23A family plasmids have a phylogeny that is distinct from that of their P. syringae hosts; (ii) whether the individual genes on pPT23A family plasmids have a phylogeny that is distinct from that of $\operatorname{rep} A$; and (iii) in situations where strains harbor more than one PFP, whether the relationship of the rep $A$ genes of those plasmids suggests intrastrain duplication events or acquisition of new plasmids.

\section{MATERIALS AND METHODS}

Bacterial strains and plasmid isolation. The bacterial strains and plasmids utilized in this study are listed in Table 1 . To extract genomic and plasmid DNA $P$. syringae strains were grown at $28^{\circ} \mathrm{C}$ overnight with continuous shaking at 250 $\mathrm{rpm}$ in mannitol-glutamate broth supplemented with $0.1 \%$ yeast extract (MGY). Genomic DNA was extracted by using the DNeasy tissue kit (QIAGEN Inc. Valencia, CA) according to the manufacturer's instructions. Plasmids were extracted by a modified alkaline lysis method $(18,54)$. Briefly, bacterial cells were resuspended in E buffer (40 mM Tris-acetate, 2 mM EDTA, pH 7.9) and lysed by the addition of 2 volumes of lysing buffer (50 $\mathrm{mM}$ Tris, $3 \%$ sodium dodecyl sulfate, $\mathrm{pH}$ 12.6). Cell lysates were then incubated at $65^{\circ} \mathrm{C}$ for $40 \mathrm{~min}$ followed by extractions with phenol-chloroform and chloroform. Plasmid DNA in the supernatants was then precipitated using ethanol and resuspended in Tris-EDTA buffer. For purification, plasmids were separated in $0.7 \%$ agarose gels in Trisacetate-EDTA buffer and then individual plasmids were isolated from the agarose gel using the QIAEX II agarose gel extraction kit (QIAGEN Inc., Valencia, CA) according to the manufacturer's instructions.

PCR amplifications and DNA sequencing. The chromosomal genes for DNA gyrase B subunit $(g y r B)$ and primary sigma factor $(r p o D)$ were amplified with the PCR primer pair gyrB-F-gyrB-R and rpoD-F-rpoD-R (Table 2), respectively (31). PCR amplifications were performed in a $50-\mu l$ reaction volume containing $1 \times$ PCR buffer, $2 \mathrm{mM} \mathrm{MgCl} 2,0.75 \mathrm{mM}$ of each deoxynucleoside triphosphate, 1 pmol of each primer, $1.0 \mathrm{U}$ Taq polymerase, and $50 \mathrm{ng}$ genomic DNA. PCR amplifications were carried out as follows: one cycle at $94^{\circ} \mathrm{C}$ for $5 \mathrm{~min}, 35$ cycles at $94^{\circ} \mathrm{C}$ for $1 \mathrm{~min}, 60^{\circ} \mathrm{C}$ for the primer pair gyrB-F-gyrB-R or $55^{\circ} \mathrm{C}$ for the primer pair rpoD-F-rpoD-R for $1 \mathrm{~min}, 72^{\circ} \mathrm{C}$ for $1.5 \mathrm{~min}$, and a final extension at $72^{\circ} \mathrm{C}$ for $10 \mathrm{~min}$. PCR products were purified using the Gel Extraction kit (QIAGEN Inc., Valencia, CA), and the purified fragments were sequenced with the primers M13-40 and M13-R (Table 2) at the Genomics Technology Support Facility at Michigan State University.

The replication gene (rep $A$ ) from individual PFPs was amplified by using the primer pair 532-F-1588-R (Table 2) (32), which flank a fragment of 1,399 bp containing $1,279 \mathrm{bp}$ of the rep $A$ coding region plus $120 \mathrm{bp}$ upstream of the putative start codon (13), and the remaining coding sequences of rep $A$ were amplified using a pair of degenerate primers, repA-F1-repA-R2 (Table 2). PCR amplifications were performed in a $50-\mu$ l reaction volume containing $1 \times \mathrm{PCR}$ buffer, $4 \mathrm{mM} \mathrm{MgCl}_{2}, 0.75 \mathrm{mM}$ of each deoxynucleoside triphosphate, $1 \mathrm{pmol}$ of each primer, 1.0 U Taq polymerase, and $1 \mu$ l purified plasmid DNA. PCR amplifications were performed using the following parameters: one cycle at $94^{\circ} \mathrm{C}$ for $5 \mathrm{~min}, 35$ cycles at $94^{\circ} \mathrm{C}$ for $1 \mathrm{~min}, 55^{\circ} \mathrm{C}$ for $1 \mathrm{~min}, 72^{\circ} \mathrm{C}$ for $1.5 \mathrm{~min}$, and a final extension at $72^{\circ} \mathrm{C}$ for $10 \mathrm{~min}$. PCR amplifications using the primer pair repAF1-repA-R2 were the same as those for the primer pair 532-F-1588-R except that $2 \mathrm{mM} \mathrm{MgCl}_{2}$ and an annealing temperature of $50^{\circ} \mathrm{C}$ were used. Additionally, the conserved hypothetical protein gene (B0046), the GntR family transcriptional regulator gene (B0077), and the TraY protein gene (traY), which are located on PFPs (40), were amplified with primer pairs B0046-F-B0046-R, B0077-F-B0077-R, and traY-F-traY-R, respectively (Table 2). These primers amplified fragments consisting of nucleotides (nt) 8 to 450 of B0046, 6 to 405 of B0077, and 211 to 1109 of traY. PCR amplifications using these primer pairs were the same as those for the primer pair repA-F1-repA-R2 except that an annealing temperature of $57^{\circ} \mathrm{C}$ was used. PCR products were purified using the Gel Extraction kit, and purified fragments were cloned into the pGEM-T Easy vector (Promega, Madison, WI) and sequenced using the primers SP6 and T7 at the Genomics Technology Support Facility at Michigan State University.

Phylogenetic analysis. Phylogenetic analyses were performed on individual gene sequences using PAUP*4.0b10 (42). Nucleotide sequences were aligned using Clustal W (43). Phylogenies were constructed in PAUP*4.0 using neighbor joining (NJ), maximum parsimony (MP), and maximum likelihood methods Neighbor joining trees were generated using the algorithm of Saitou and Nei (29) with Kimura two-parameter distances. Maximum parsimony and maximum likelihood analyses employed heuristic searches with 10 sequences of random taxon addition and tree bisection and reconnection (TBR) branch swapping. Appropriate evolutionary models for use in maximum likelihood analyses were determined for each data set using Modeltest version 3.7 (25). The NJ tree was specified as the starting tree for maximum likelihood searches. Support for groups obtained in phylogenetic analyses was assessed by bootstrap analysis using PAUP*4.0. We assessed congruence between phylogenetic trees obtained using different gene sequences by comparing the trees with respect to bootstrap support for alternate groupings. Support for alternate placements between the same taxa in different trees was considered to exist when the two different data sets both provided strong support for the competing relationships (50).

Analysis of repA nucleotide diversity. Sliding window analysis of rep $A$ nucleotide diversity $\pi$ was conducted using the program DnaSP version 3.51 (28). The alignment consisted of 1,314 nucleotides of the rep $A$ coding region. Sites with gaps (positions 1120 to 1131 of rep $A$ nucleotide sequences) were excluded from the analysis. $\pi$ is the average number of nucleotide differences per site between two sequences, and the sliding window method allows a value of $\pi$ to be assigned at the midpoint of a window of defined length. In our analysis, we used a window of 100 nucleotides and measured $\pi$ every 5 nucleotides. 
TABLE 1. Pseudomonas syringae strains, plasmids, and sequences used in this study

\begin{tabular}{|c|c|c|c|c|c|c|c|c|c|c|c|}
\hline Genomospecies & $\begin{array}{l}\text { P. syringae } \\
\text { pathovar }\end{array}$ & Strain & Host & $r p o D$ & $\operatorname{gyr} B$ & Plasmid $^{b}$ & repA & $\operatorname{tra} Y$ & B0046 & B0077 & $\begin{array}{l}\text { Reference/ } \\
\text { source }^{d}\end{array}$ \\
\hline \multirow[t]{6}{*}{ I } & \multirow[t]{2}{*}{ pisi } & \multirow[t]{2}{*}{$870 \mathrm{~A}$} & \multirow[t]{2}{*}{ Pea } & \multirow[t]{2}{*}{ AB016388 } & \multirow[t]{2}{*}{ AB016387 } & pAV230 & $\mathrm{X}^{a}$ & $-^{c}$ & - & - & 9 \\
\hline & & & & & & pAV231 & $\mathrm{X}$ & - & - & - & \\
\hline & \multirow[t]{4}{*}{ syringae } & $\mathrm{A} 2$ & $\begin{array}{l}\text { Ornamental } \\
\text { pear }\end{array}$ & $X$ & $\mathrm{X}$ & pPSR1 & $X$ & - & - & - & 40 \\
\hline & & B86-17 & Snap bean & $\mathrm{X}$ & $\mathrm{X}$ & pB86-17A & $\mathrm{X}$ & - & - & - & 41 \\
\hline & & HS191 & Millet & $\mathrm{X}$ & $\mathrm{X}$ & pCG131 & $\mathrm{X}$ & $X$ & $\mathrm{X}$ & & 33 \\
\hline & & 4918 & Butterfly pea & $\mathrm{X}$ & $\mathrm{X}$ & pPSS4918 & $\mathrm{X}$ & - & - & - & AKV \\
\hline \multirow[t]{22}{*}{ II } & \multirow[t]{3}{*}{ aesculi } & \multirow[t]{3}{*}{$0893-23$} & \multirow[t]{3}{*}{$\begin{array}{l}\text { Indian horse } \\
\text { chestnut }\end{array}$} & \multirow[t]{3}{*}{$\mathrm{X}$} & \multirow[t]{3}{*}{$\mathrm{X}$} & pPA0893A & $\mathrm{X}$ & - & - & $\mathrm{X}$ & \multirow[t]{3}{*}{ DAC } \\
\hline & & & & & & pPA0893B & $\mathrm{X}$ & - & - & $\mathrm{X}$ & \\
\hline & & & & & & pPA0893C & $\mathrm{X}$ & - & - & $\mathrm{X}$ & \\
\hline & ciccaronei & 2342 & Carob tree & $\mathrm{X}$ & $\mathrm{X}$ & $\mathrm{p} 2342 \mathrm{~A}$ & $\mathrm{X}$ & $\mathrm{X}$ & $\mathrm{X}$ & $\mathrm{X}$ & 12 \\
\hline & \multirow[t]{2}{*}{ glycinea } & \multirow[t]{2}{*}{ Race 6} & \multirow[t]{2}{*}{ Soybean } & \multirow[t]{2}{*}{ AB016324 } & \multirow[t]{2}{*}{ AB016323 } & pREP601 & $\mathrm{X}$ & - & - & - & 32 \\
\hline & & & & & & pREP603 & $X$ & - & - & - & \\
\hline & mori & 1642 & Mulberry & $\mathrm{X}$ & $\mathrm{X}$ & p1642A & $\mathrm{X}$ & - & - & $\mathrm{X}$ & DAC \\
\hline & phaseolicola & 1390 & Snap bean & $X$ & $\mathrm{X}$ & p1390A & $X$ & $\mathrm{X}$ & $\mathrm{X}$ & $\mathrm{X}$ & DAC \\
\hline & & & & & & p1390C & $X$ & $\mathrm{X}$ & $\mathrm{X}$ & $\mathrm{X}$ & \\
\hline & & $1302 \mathrm{~A}$ & Snap bean & & & pAV505 & $\mathrm{X}$ & - & - & - & 15 \\
\hline & & 1449B & Snap bean & & & pAV511 & $X$ & - & - & - & 15 \\
\hline & & & & & & pAV512 & $\mathrm{X}$ & - & - & - & \\
\hline & & $1448 \mathrm{~A}$ & Snap bean & AAZ36734 & AAZ34879 & $\mathrm{pPh} 1448 \mathrm{~A}$ & $\mathrm{X}$ & - & - & - & 17 \\
\hline & & & & & & pPh1448B & $\mathrm{X}$ & - & - & - & \\
\hline & savastanoi & $0485-9$ & Oleander & $\mathrm{X}$ & $\mathrm{X}$ & pPS0485A & $\mathrm{X}$ & - & - & $\mathrm{X}$ & $\mathrm{JM}$ \\
\hline & & & & & & pPS0485B & $\mathrm{X}$ & - & - & $\mathrm{X}$ & \\
\hline & & & & & & pPS0485C & $X$ & - & - & $\mathrm{X}$ & \\
\hline & & 0693-10 & Oleander & $\mathrm{X}$ & $\mathrm{X}$ & pPS0693A & $\mathrm{X}$ & - & - & $\mathrm{X}$ & DAC \\
\hline & & 1670 & Olive & $\mathrm{X}$ & $\mathrm{X}$ & p1670A & $X$ & - & - & $\mathrm{X}$ & DAC \\
\hline & & & & & & $\mathrm{p} 1670 \mathrm{~B}$ & $\mathrm{X}$ & - & - & $\mathrm{X}$ & \\
\hline & tabaci & 0893-29 & Tobacco & $X$ & $\mathrm{X}$ & pPSTA0893A & $\mathrm{X}$ & $\mathrm{X}$ & $\mathrm{X}$ & $\mathrm{X}$ & DAC \\
\hline & & & & & & & & & & & \\
\hline III & maculicola & & Crucifers & AY610898 & AY610778 & $\mathrm{pFKN}$ & $\mathrm{X}$ & - & - & - & 26 \\
\hline & & ES4326 & Crucifers & AY610897 & AY610777 & pPMA4326A & $\mathrm{X}$ & - & - & - & 34 \\
\hline & & & & & & pPMA4326B & $\mathrm{X}$ & - & - & - & \\
\hline & & 88.10 & Cauliflower & $\mathrm{X}$ & $\mathrm{X}$ & pPSM 8810 & $\mathrm{X}$ & $\mathrm{X}$ & - & $\mathrm{X}$ & 49 \\
\hline & & 90.32 & Cauliflower & $X$ & $X$ & pPSM9032A & $\mathrm{X}$ & $\mathrm{X}$ & $\mathrm{X}$ & - & 10 \\
\hline & & & & & & pPSM9032B & $X$ & $\mathrm{X}$ & $\mathrm{X}$ & $\mathrm{X}$ & \\
\hline & persicae & 1573 & Peach & $\mathrm{X}$ & $\mathrm{X}$ & $\mathrm{p} 1573 \mathrm{C}$ & $\mathrm{X}$ & $\mathrm{X}$ & $\mathrm{X}$ & $\mathrm{X}$ & 12 \\
\hline & tomato & DC3000 & Tomato & NC 004578 & NC 004578 & pDC3000A & $\mathrm{X}$ & $X$ & - & - & 6 \\
\hline & & & & & & pDC3000B & $\mathrm{X}$ & - & $\mathrm{X}$ & $\mathrm{X}$ & \\
\hline & tomato & UPN2A & Tomato & $\mathrm{X}$ & $\mathrm{X}$ & pPT23A & $\mathrm{X}$ & $\mathrm{X}$ & $\mathrm{X}$ & $\mathrm{X}$ & 33 \\
\hline & & UPN2B & Tomato & & & pРT23B & $\mathrm{X}$ & $X$ & $\mathrm{X}$ & $\mathrm{X}$ & 32 \\
\hline & & OK-1 & Tomato & $\mathrm{X}$ & $\mathrm{X}$ & pOK-1A & $\mathrm{X}$ & $\mathrm{X}$ & $\mathrm{X}$ & $\mathrm{X}$ & 33 \\
\hline IV & garcae & 2708 & Coffee & $\mathrm{X}$ & $\mathrm{X}$ & pPG2708 & $\mathrm{X}$ & $\mathrm{X}$ & $\mathrm{X}$ & $\mathrm{X}$ & NCPPB \\
\hline & & 1634 & Coffee & $\mathrm{X}$ & $\mathrm{X}$ & p1634A & $\mathrm{X}$ & $\mathrm{X}$ & & $\mathrm{X}$ & 13 \\
\hline & & & & & & p1634B & $\mathrm{X}$ & $\mathrm{X}$ & & $\mathrm{X}$ & \\
\hline $\mathrm{V}$ & tremae & 6111 & $\begin{array}{l}\text { Trema } \\
\quad \text { orientalis }\end{array}$ & $\mathrm{X}$ & $\mathrm{X}$ & p6111A & $\mathrm{X}$ & - & - & - & 12 \\
\hline VIII & avellanae & 4060 & Hazelnut & & & p4060B & $X$ & $\mathrm{X}$ & $X$ & $\mathrm{X}$ & 12 \\
\hline & & & & & & $\mathrm{p} 4060 \mathrm{C}$ & $\mathrm{X}$ & $X$ & - & $X$ & \\
\hline & theae & 2353 & Tea & $\mathrm{X}$ & $\mathrm{X}$ & $\mathrm{p} 2353 \mathrm{~B}$ & $\mathrm{X}$ & $X$ & $\mathrm{X}$ & $\mathrm{X}$ & 12 \\
\hline Outgroup & & LRB3W1 & & AB204720 & AB204718 & & & & & & \\
\hline
\end{tabular}

${ }^{a}$ New sequences obtained in this study are designated by an $\mathrm{X}$.

${ }^{b}$ GenBank accession numbers for complete plasmid sequences are as follows: pDC3000A, NC 004633; pDC3000B, NC 004632; pFKN, NC 002759; pPSR1, NC_005205; pPMA4326A, NC_005918; pPMA4326B, NC_005919; pPH1448A, NC_007274; pPH1448̄B, NC_007275.

$c^{-}$- indicates that the sequence was not recovered from the plasmid.

${ }^{d}$ Abbreviations: AKV, A. K. Vidaver; DAC, D. A. Cooksey; JM, J. Murillo; NCPPB, National Collection of Plant Pathogenic Bacteria, Sand Hutton, York, United Kingdom.

Nucleotide sequence accession numbers. GenBank accession numbers for sequences of the chromosomal genes gyrB and $r p o D$ and the plasmid genes rep $A$, B0046, B0077, and traY sequenced in this study were DQ072672 to DQ072693, DQ072694 to DQ072715, DQ072594 to DQ072607, DQ072608 to DQ072633, and DQ072634 to DQ072651, respectively.

\section{RESULTS}

Phylogenies of chromosomal genes. The chromosomal genes gyrB and $r p o D$ were adopted here to determine the course of $P$. syringae genome evolution since they are indispensable single- 
TABLE 2. PCR primers used in this study

\begin{tabular}{|c|c|c|c|}
\hline Primer & Sequence $\left(5^{\prime}-3^{\prime}\right)$ & $T_{m}\left({ }^{\circ} \mathrm{C}\right)$ & Target gene or description \\
\hline $532-\mathrm{F}$ & GAACGGTGGACTTATGG & 53 & Replication gene (rep $A)$ \\
\hline 1588-R & CTCCAGCTTGCGGCCCC & & \\
\hline repA-F1 & AGCTTCAAGAYCAGGGMAA & 50 & герA \\
\hline repA-R2 & ARRTCCATCARYCGGTCRAA & & \\
\hline B0046-F & ATTGGCGTGTTTTGATGCAC & 57 & $\begin{array}{l}\text { Conserved hypothetical } \\
\text { protein gene (B0046) }\end{array}$ \\
\hline B0046-R & AAGGAAAGCCGCTCTACGG & & \\
\hline B0077-F & TAACCGCAAAACGCAGAAAC & 57 & $\begin{array}{l}\text { GntR family transcriptional } \\
\text { regulator gene (B0077) }\end{array}$ \\
\hline B0077-R & ACCCAGGACACGCAGGATTT & & \\
\hline traY-F & ATTATCAATGGCGTTCTGGC & 57 & TraY protein gene $(\operatorname{tra} Y)$ \\
\hline traY-R & TGCTCGCCCAGATTACTCAT & & \\
\hline gyrB-F & CGCCAGGGTTTTCCCAGTCACGACCMGGCGGYAAGTTCGATGACAAYTC & 60 & DNA gyrase B subunit $(g y r B)$ \\
\hline gyrB-R & TTTCACACAGGAAACAGCTATGACTRATBKCAGTCARACCTTCRCGSGC & & \\
\hline rpoD-F & CGCCAGGGTTTTCCCAGTCACGACAAGGCGARATCGAAATCGCCAAGCG & 55 & Primary sigma factor $(r p o D)$ \\
\hline rpoD-R & TTTCACACAGGAAACAGCTATGACGGAACWKGCGCAGGAAGTCGGCACG & & \\
\hline M13-40 & CGCCAGGGTTTTCCCAGTCACGAC & & Sequencing primers \\
\hline M13-R & TTTCACACAGGAAACAGCTATGAC & & \\
\hline
\end{tabular}

copy genes on which horizontal gene transfer seldom occurs and are widely accepted indices for phylogenetic analyses previously utilized for studies involving $P$. syringae and the Pseudomonas genus $(30,31,51)$. Comparison of phylogenies constructed from sequences of plasmid genes and phylogenies constructed from sequences of conserved chromosomal genes is an effective method to evaluate the association of specific plasmid types with specific host chromosomal genotypes. In this study, we analyzed in both separate and simultaneous (combined) analyses (7) the partial sequences of gyrB (471 bp) and rpoD (462 bp) genes from $28 P$. syringae strains, which belong to 16 pathovars of $P$. syringae and represent six genomospecies (Table 1).

The neighbor joining tree obtained via analysis of the combined (concatenated) gyrB/rpoD data set (Fig. 1) shows that the genomospecies of $P$. syringae, in general, cluster together very well (with the notable exception of $P$. syringae pv. maculicola ES4326, which has been noted previously as an "oddball" strain [30]). Maximum parsimony analysis of the gyrB/rpoD data set yielded four equally parsimonious trees (tree length, 418; consistency index, 0.565 ; retention index, 0.829), which were virtually identical to the NJ tree, except for the positions of taxa within two terminal clusters (P. syringae pv. savastanoi/ ciccaronei and tomato/maculicola). Modeltest 3.7 was used to determine whether the Tamura-Nei DNA substitution model allowing invariant sites and applying a gamma rate parameter $(\operatorname{TrN}+\mathrm{I}+\mathrm{G})$ was the appropriate model of DNA sequence evolution for the $g y r B / r p o D$ data set. The maximum likelihood tree was identical to the NJ tree, with the exception that the positions of $P$. syringae pv. tabaci 0893 to 29 and the $P$. syringae pv. aesculi 0893 to $23 / P$. syringae pv. tremae 6111 cluster were reversed.

Four major clusters in the NJ tree were supported by bootstrap values of $>95$ in both the NJ analysis and the MP analysis (Fig. 1). First, the genomospecies I strains formed a coherent cluster. Second, there was a cluster consisting of strains belonging to genomospecies groups II and V (V has one strain in the data set, $P$. syringae pv. tremae). A cluster consisting of these first two major clusters was strongly supported by bootstrap analysis. Third, there was a cluster consisting of genomo- species IV strains. Finally, there was a cluster consisting of strains in genomospecies III and VIII, excluding $P$. syringae pv. maculicola ES4326.

We also analyzed the data from gyrB and $r p o D$ separately. Trees resulting from these analyses each contained all four of the major clusters (described above) and differed only slightly from the combined tree with respect to the position of taxa within the four major clusters (data not shown).

Replication genes $(\operatorname{rep} A)$ of the pPT23A family plasmids. Since the rep $A$ gene is essential for replication of the PFPs and is the only gene currently known to be distributed among all the plasmids, analysis of rep $A$ is appropriate in determining phylogenetic relationships among the PFPs. To analyze the phylogenetic relationship of PFPs, we cloned and sequenced the complete rep $A$ gene from 38 PFPs and included rep $A$ sequences from nine previously sequenced alleles (Table 1 ). Phylogenetic analysis of rep $A$ sequences showed that the 47 rep $A$ genes from $P$. syringae were clustered into four distinct groups with very high bootstrap support (Fig. 2). Analysis of plasmid host in conjunction with rep $A$ phylogeny indicated that the rep $A$ genes were not clustered based on the host strain of their plasmid or pathovar. Plasmids coexisting within single bacterial strains were either clustered into the same group (e.g., p1634A and $\mathrm{p} 1634 \mathrm{~B}$ in group B and pPMA4326A and pPMA4326B in group D) or into different groups (e.g., pPT23B and pPT23A in groups $\mathrm{A}$ and $\mathrm{B}$, respectively). Many plasmids from different strains belonging to different pathovars shared high levels of rep $A$ nucleotide identity. These results indicated that $\operatorname{rep} A$ from PFPs has a phylogeny that is distinct from that of the $P$. syringae hosts of these plasmids.

Sliding window analysis of nucleotide divergence of the rep $A$ coding region showed that high levels of variability were observed from nucleotide positions 1000 to 1314 (Fig. 3). This result is in agreement with a previous report that the RepA proteins from PFPs were poorly conserved from residues 374 to 437 at their $\mathrm{C}$-terminal ends but conserved from residues 1 to 373 at their N-terminal ends (33). Additionally, a 12-nt deletion located at $11 \mathrm{nt}$ before the start codon ATG of repA was found in 10 plasmids, which were distributed among different $P$. syringae pathovars (data not shown). The 10 plasmids 


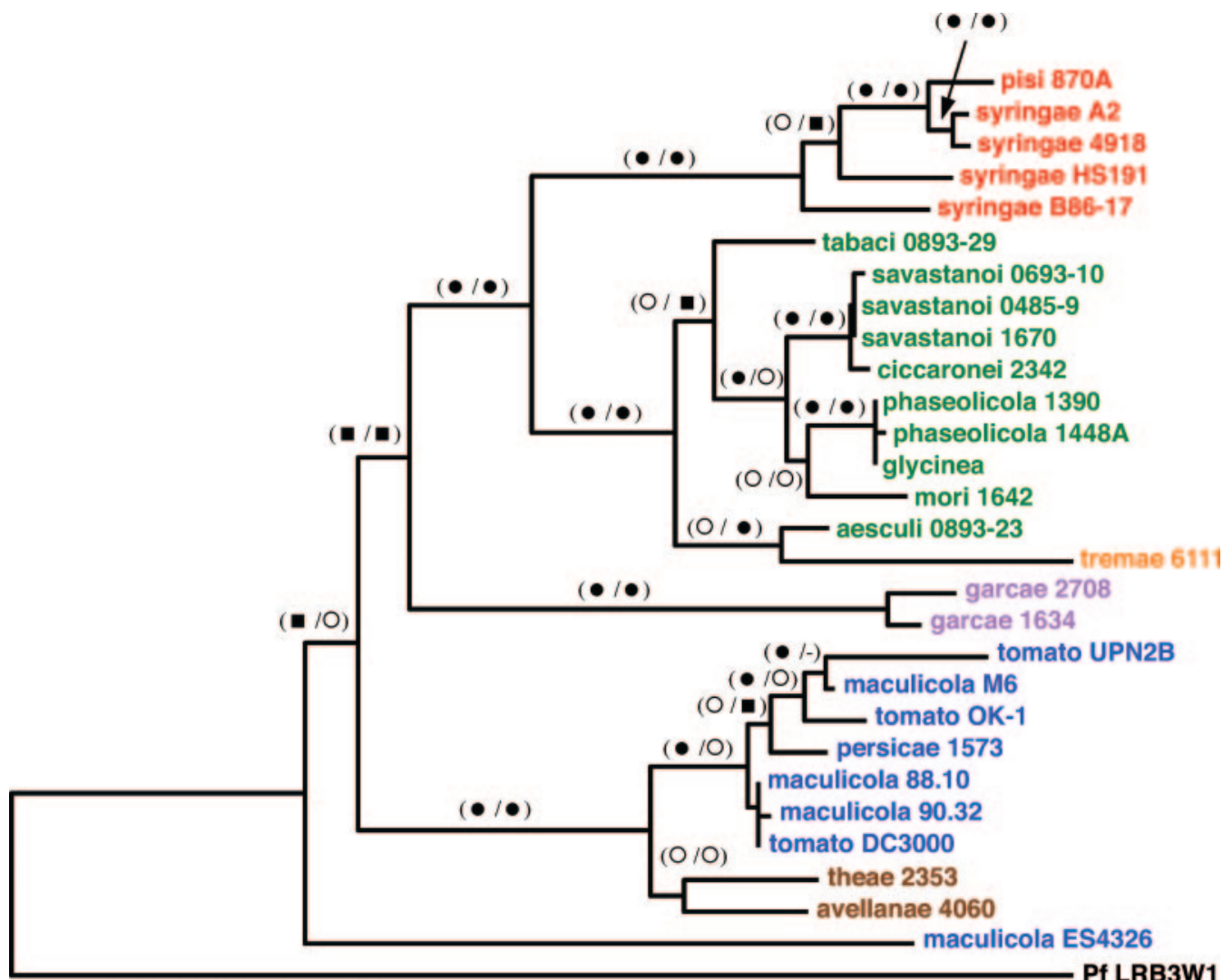

- 0.01 substitutions/site

FIG. 1. Phylogenetic analysis of the concatenated gyrB-rpoD (genomic) data set from 28 Pseudomonas syringae strains with Pseudomonas fluorescens LRB3W1 as the outgroup. The tree shown was obtained by NJ using Kimura two-parameter distances. Symbols on branches show bootstrap values with both the NJ (1,000 replicates) and MP (1,000 replicates) bootstrap values shown in parentheses (NJ/MP). Symbols for bootstrap values: $->90 ; \bigcirc, 70$ to $90 ; \mathbf{\square}, 50$ to $70 ;-,<50$. Taxa are color coded by genomospecies (13) as follows: red, genomospecies I; green, genomospecies II; blue, genomospecies III; purple, genomospecies IV; orange, genomospecies V; brown, genomospecies VIII.

having the 12-nt deletion were clustered into different groups based on nucleotide sequences of the $\operatorname{rep} A$ coding region (pPSS4918 and pPSM9032A in group A; pPG2708 and pOK-1A in group $\mathrm{B}$; and the remaining six plasmids $\mathrm{pPS} 0485 \mathrm{~A} / \mathrm{B} / \mathrm{C}$, p1670B, p2342A, and p6111A in group C) (Fig. 2). These results indicated that the 12-nt deletion upstream of rep $A$ is not associated with nucleotide sequences of the $\operatorname{rep} A$ coding region.

Phylogenies of other genes on PFPs. Except for rep $A$, no other gene is known to be distributed among all the PFPs examined (54). The conserved hypothetical protein gene (B0046), the GntR family transcriptional regulator gene (B0077), and the TraY protein gene (traY) were selected for phylogenetic analyses of genes other than repA on PFPs because these genes were found to be distributed among a large number of PFPs and on PFPs from different groups based on the type IV secretion system encoded (54). Since the plasmid pPG2708 had all three genes examined, it was used as an outgroup for the phylogenetic trees of B0077, B0046, and traY. Phylogenetic analysis of DNA sequences of B0046, B0077, and tra $Y$ showed that individual genes on PFPs had a phylogeny that was distinct from that of rep $A$ (Fig. 2 and 4). Thus, groups supported well by bootstrap analysis in the B0077, traY, and B0046 trees are in different places compared to the rep $A$ tree. For example, based on nucleotide sequences of $\operatorname{rep} A$, the plas- mids $\mathrm{p} 4060 \mathrm{~B}$ and $\mathrm{p} 2342 \mathrm{~A}$ from $P$. syringae pv. avellanae and ciccaronei, respectively, are grouped together (Fig. 2); however, the B0077 and traY sequences from these plasmids are placed in different groups (Fig. 4). Conversely, both the traY and B0046 sequences from pOK-1A and pPT23B and from $\mathrm{p} 1390 \mathrm{~A}$ and $\mathrm{p} 1390 \mathrm{C}$ were similar; however, the rep $A$ genes from these two sets of plasmids were phylogenetically distinct (Fig. 2 and 4).

Although phylogenies of three genes on PFPs were different from each other (Fig. 4), we observed that the plasmids pPSM8810 and p1390C isolated from genomospecies III and II, respectively, had nearly identical sequences of B0077. Similarly, the plasmids pPSM8810, pDC3000A, pPSM9032A, and pPSM9032B from genomospecies III and the plasmid pCG131 from genomospecies I also had nearly identical sequences of traY. These results indicated that interplasmid transfer of genes might have occurred among PFPs in strains of different $P$. syringae genomospecies.

\section{DISCUSSION}

The pPT23A plasmid family of $P$. syringae is defined as a group of plasmids presumed to share a common ancestor with all members containing the conserved essential replication 


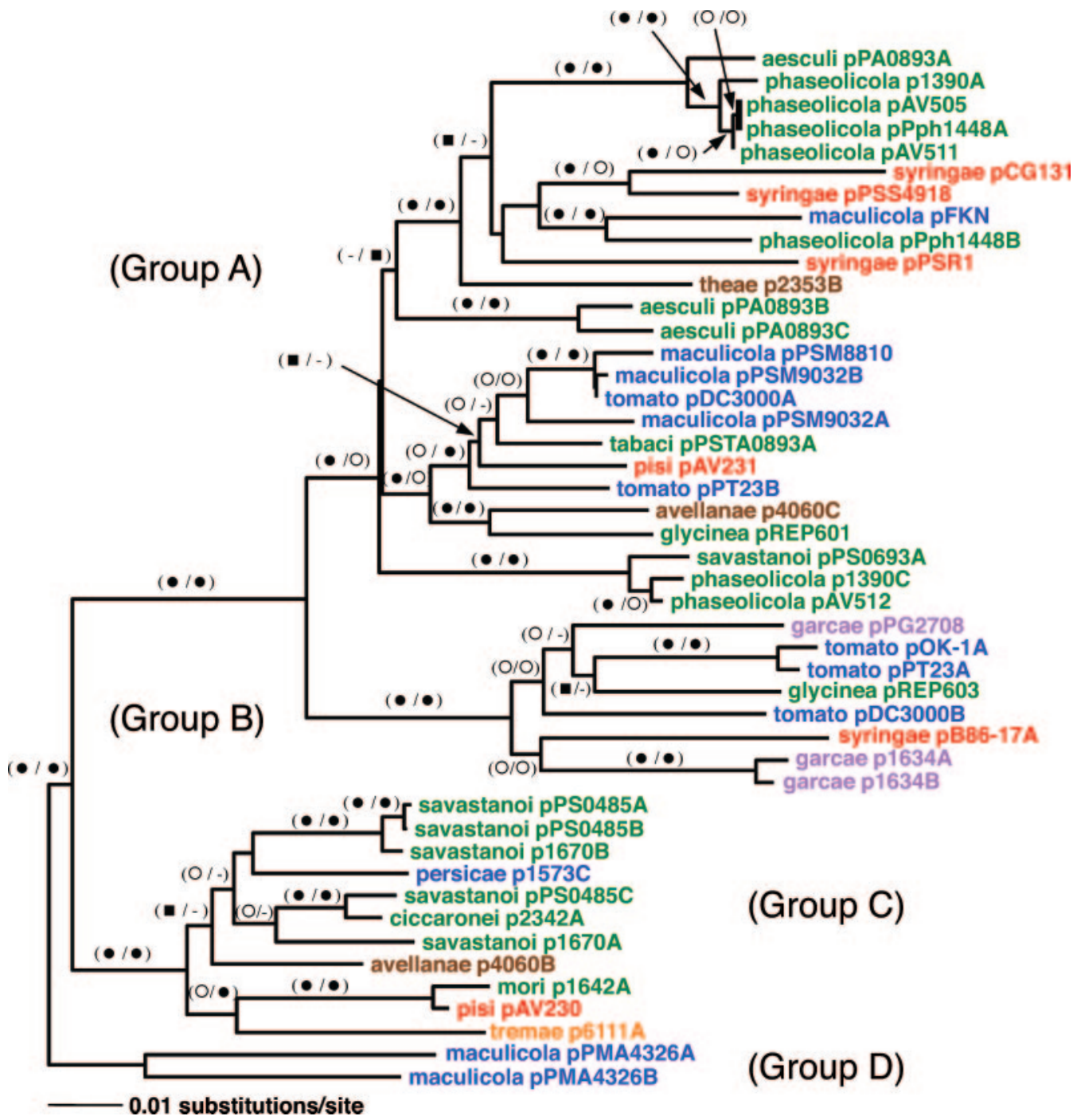

FIG. 2. Phylogenetic analysis of full nucleotide sequences of repA of pPT23A family plasmids from Pseudomonas syringae, using the repA sequences of $P$. syringae pv. maculicola pPMA4326A and pPMA4326B as the outgroup. The tree shown was obtained by neighbor joining using Kimura two-parameter distances. Symbols on branches show bootstrap values with both the NJ (1,000 replicates) and MP (1,000 replicates) bootstrap values shown in parentheses (NJ/MP). Symbols for bootstrap values: $\bullet,>90 ; \bigcirc, 70$ to $90 ; \mathbf{\square}, 50$ to 70 ; -, $<50$. Plasmids are color coded by the genomospecies (13) of the pathovars from which they were isolated as follows: red, genomospecies I; green, genomospecies II; blue, genomospecies III; purple, genomospecies IV; orange, genomospecies V; brown, genomospecies VIII.

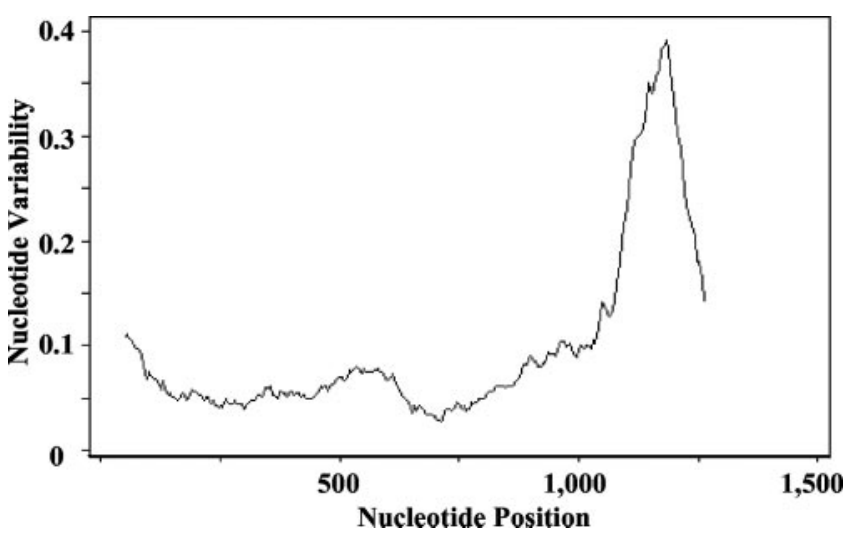

FIG. 3. Sliding window analysis of repA nucleotide diversity $(\pi)$ using the computer program DnaSP. The alignment consisted of 1,314 nucleotides. Sites with gaps (positions 1120 to 1131 of rep $A$ nucleotide sequences) were excluded from the sliding window analysis. gene repA. With the current known distribution of PFPs in $P$. syringae now expanded to 28 of 51 known pathovars from six of nine known genomospecies, we hypothesize that PFPs are universally distributed among pathovars of this species. Our data indicated that the phylogeny of $\operatorname{rep} A$ is distinct from that of the $P$. syringae host, suggesting that the intrapathovar and interpathovar transfer of PFPs among strains has affected the observed distribution of these plasmids today. pPT23A family plasmids are maintained within $P$. syringae populations through at least three mechanisms: (i) vertical transmission through replication and partitioning of plasmid copies to bacterial daughter cells during cell division, (ii) horizontal transmission via transfer mechanisms such as conjugation, and (iii) integration of plasmid DNA into the host chromosome. The maintenance of PFPs in $P$. syringae strains is also apparently facilitated through the contribution of PFP-carried genes to the 


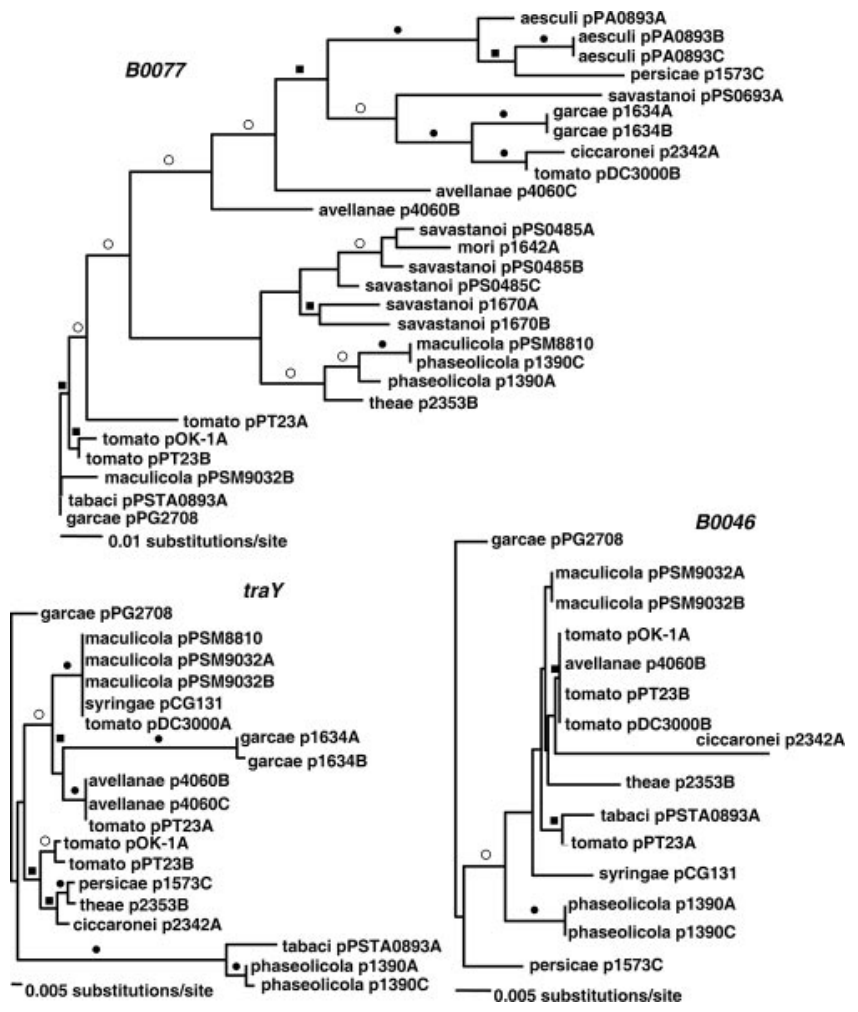

FIG. 4. Neighbor joining analyses using Kimura two-parameter distances of partial nucleotide sequences of plasmid-carried genes from pPT23A family plasmids, using sequences from the $P$. syringae pv. garcae plasmid pPG2708 as the outgroup to allow comparisons across the three genes: B0077 (238 bp), traY (294 bp), and B0046 (285 bp). Symbols on branches show NJ bootstrap values (1,000 replicates). Symbols for bootstrap values: $\bullet,>90 ; \bigcirc, 70$ to $90 ; \mathbf{\square}, 50$ to 70 .

ecological fitness and/or virulence of host cells. Thus, an understanding of the evolution of the pPT23A plasmid family in $P$. syringae requires knowledge of plasmid distribution and the distribution of plasmid-specific genes within the divergent pathovars of this species and delineation of the phylogenetic relationships of these genetic determinants. Phylogenetic studies of plasmids must also be framed with the realization that horizontal transfer contributes to plasmid evolution both by providing new bacterial hosts to which the plasmid may be better adapted and by providing opportunities for the acquisition of novel genes.

Conjugation of PFPs has been demonstrated previously, typically involving intrapathovar transfer of plasmids containing bactericide resistance markers $(8,40)$. Recently, two distinct putative conjugative transfer systems were uncovered in genome sequencing projects $(6,35)$. Both of these type IV secretion systems were similar to those found in other plantassociated bacteria (54), implying that horizontal plasmid transfer is an important factor in the evolution of plantpathogenic bacteria. Indeed, although the rhizosphere represents an environmental hot spot for plasmid transfer, conjugation can readily occur in the phyllosphere, a location where most $P$. syringae strains can establish relatively large populations $(4,11,45)$.

Horizontal transfer of PFPs is the best explanation for our observation of the phylogenetic incongruence between the rep $A$ gene of many PFPs and their current bacterial (P. syringae pathovar) host. The frequency of occurrence of plasmid transfer between strains remains unknown as is knowledge of the partners in potential interpathovar mating events. In addition, the transfer of PFPs between $P$. syringae strains could yield unpredictable results in that almost all $P$. syringae strains surveyed already contain at least one PFP. We highlight three possible scenarios involving PFP transfer in $P$. syringae. (i) The donor plasmid is compatible with the preexisting PFP in the recipient. Both plasmids can be maintained as separate entities; however, if the plasmids contain homologous sequences, recombination can occur, leading to gene reassortment among plasmids. Gene reassortments would result in phylogenetic incongruence between individual genes and the PFP repA gene, as shown in our data (Fig. 4). (ii) The donor plasmid is incompatible with the preexisting PFP in the recipient. During the eventual eviction of one of the plasmids, mobile elements present on the lost plasmid are transposed to the plasmid maintained in the cell. The transposition of the streptomycin resistance transposon Tn5393 to a novel PFP was demonstrated to occur in this manner (36). A large number of mobile elements, including several insertion sequences, have been detected on PFPs, and the current pathovar distribution of these elements may be reflected in various plasmid transfer events. (iii) The donor plasmid is compatible with the preexisting PFP in the recipient and contains homologous sequences resulting in a recombination event that also involves an extensive duplication. The existence of coresident PFPs containing an extensive amount of duplicated DNA has been shown in at least two $P$. syringae pv. tomato strains $(6,20)$.

It is generally accepted that plasmids that have related sequences functioning in replication or partition cannot be stably maintained within single cells due to incompatibility effects (3, 21). In this study, however, we observed that some PFPs having closely related $\operatorname{rep} A$ sequences could coexist within single bacterial strains. It was previously postulated that those plasmids might contain another functional origin of replication (32). However, recent sequencing analyses have shown that the coexisting plasmids pDC3000A and pDC3000B in P. syringae pv. tomato DC3000 and pPMA4326A and pPMA4326B coexisting in $P$. syringae pv. maculicola ES4326 carried only a single replication gene $(6,34)$, which suggested that these PFPs might have evolved a mechanism allowing them to escape incompatibility. For example, although the RepA proteins of pPMA4326A and $-\mathrm{B}$ shared $96 \%$ amino acid identity, they differed in the sequence of a 19-bp putative stem-loop structure located 221 bp upstream of $\operatorname{rep} A$, which might be complementary to the replication protein $\mathrm{C}$ terminus (34), thereby enabling these two plasmids to coexist in one strain.

Our sequencing data for rep $A$ genes from coexisting PFPs from $14 P$. syringae strains further suggest that two mechanisms influence the cooccurrence of multiple PFPs in individual strains. The RepA sequences from coexisting plasmids from six strains $(P$. syringae pv. phaseolicola 1448A, $P$. syringae pv. savastanoi 0485-9 and $1670, P$. syringae pv. maculicola $90-32$ and ES4326, and $P$. syringae pv. garcae 1634) were highly similar (Fig. 2), indicating a possibility that microevolutionary mutational alterations resulted in the evolution and stable coexistence of two distinct plasmids. We hypothesize that mutations affecting the RepA amino acid sequence in conjunction with changes affecting the DNA origin of replication target site would optimize this compatible arrange- 
TABLE 3. Distribution of selected genes carried on pPT23A family plasmids among Pseudomonas syringae pathovars and genomospecies ${ }^{a}$

\begin{tabular}{|c|c|c|c|c|c|}
\hline $\mathrm{Gene}^{b}$ & Gene product & Function & $\begin{array}{l}\text { Genomic } \\
\operatorname{location}(\mathrm{s})\end{array}$ & $\begin{array}{l}\text { No. of pvs., } \\
\text { gnms }\end{array}$ & Reference(s) \\
\hline avrD & Effector & $\mathrm{V}$ & $\mathrm{P}$ & 19,5 & 53 \\
\hline avrPphD & Type III effector & V & $\mathrm{P}$ & 4,3 & 54 \\
\hline cor & Coronatine toxin synthesis & $\mathrm{V}$ & $\mathrm{P}, \mathrm{C}$ & 5,3 & 1 \\
\hline efe & Ethylene synthesis & $\mathrm{V}$ & $\mathrm{P}$ & 5,3 & 48 \\
\hline iaaM & Tryptophan 2-monooxygenase & $\mathrm{V}$ & $\mathrm{P}, \mathrm{C}$ & 12,4 & 14 \\
\hline $\operatorname{virPph} A$ & Type III effector & $\mathrm{V}$ & $\mathrm{P}, \mathrm{C}$ & 7,2 & $15,16,54$ \\
\hline$i a a L$ & Indole 3 -acetic acid-lysine synthetase & Ep & $\mathrm{P}, \mathrm{C}$ & 38,7 & 14 \\
\hline$l s c$ & Levansucrase & Ep & $\mathrm{P}$ & 5,3 & 54 \\
\hline$m c p$ & Chemotaxis transducer & $\mathrm{Ep}$ & $\mathrm{P}$ & 3,3 & 54 \\
\hline $\operatorname{rul} A B$ & UV radiation tolerance & Ep & $\mathrm{P}, \mathrm{C}$ & 17,4 & 41,54 \\
\hline герA & Plasmid replication & $\mathrm{Pl}$ & $\mathrm{P}$ & 28,6 & This study \\
\hline $\operatorname{tra} Y$ & Conjugation & $\mathrm{Pl}$ & $\mathrm{P}$ & 7,3 & 54 \\
\hline $\operatorname{virB4}$ & Conjugation & $\mathrm{Pl}$ & $\mathrm{P}$ & 8,4 & 54 \\
\hline IS801 & Insertion sequence & MGE & $\mathrm{P}, \mathrm{C}$ & 10,4 & 1,54 \\
\hline B0046 & Conserved hypothetical protein & $\mathrm{U}$ & $\mathrm{P}$ & 9,5 & This study \\
\hline B0077 & GntR family regulator & $\mathrm{R}$ & $\mathrm{P}$ & 13,4 & This study \\
\hline
\end{tabular}

${ }^{a}$ Abbreviations: C, chromosome; Ep, epiphytic fitness; gnms., genomospecies; MGE, mobile genetic element; P, plasmid; pvs., pathovars; Pl, plasmid related; R, regulatory; $\mathrm{U}$, unknown; $\mathrm{V}$, virulence.

${ }_{b}$ New designations for effector genes: $\operatorname{avrD}=\operatorname{avrD1}$; $\operatorname{avPphD}=$ hopD1; $\operatorname{virPh} A=$ hop $A B 1$.

ment through rendering each RepA protein specific for its cognate origin sequence. The RepA sequences from coexisting plasmids from seven other strains ( $P$. syringae pv. pisi 870A, $P$. syringae pv. glycinea Race 6, P. syringae pv. phaseolicola 1390 and 1449B, P. syringae pv. tomato DC3000 and PT23, and P. avellanae 11144) were distinct and, in most cases, separated into different phylogenetic groups (Fig. 2). In these situations, it is most likely that at least one of the multiple coexisting PFPs was acquired by horizontal transfer. The $P$. syringae pv. aesculi strain 0893-23 was unique in that the strain contained two plasmids with highly similar RepA sequences (pPA0893B and pPA0893C) and a third plasmid (pPA0893A) with a distinct RepA sequence (Fig. 2).

Thus, the pPT23A plasmid family represents a dynamic genome subject to recombination, gene acquisition, gene exchange, and gene delivery to new $P$. syringae hosts. These plasmids represent genetic mosaics, structures that have been observed with many bacterial plasmids (22), and in addition to encoding type III effectors, individual PFPs have been found to carry genes directing the production of the phytotoxin coronatine, epiphytic fitness determinants, and plasmid-specific functions and genes with known homologs whose significance for $P$. syringae fitness remains unknown (1, 2, 6, 14, 15, 16, 34, 40, 46). An analysis of the pathovar distribution of individual genes known to be carried on PFPs illustrates alternative broad and narrow pathovar ranges of specific genes (Table 3 ). The genomospecies distribution of these genes suggests that many of these sequences are highly mobile within the $P$. syringae species. Genes encoding proteins with plasmid-specific functions or functions predicted to determine traits of general ecological importance to the $P$. syringae species are the most widely distributed; in contrast, certain type III effector genes and other virulence determinants are only rarely observed in the $P$. syringae species (Table 3). In addition, some genes such as iaaL and iaa $M$ are chromosomally located in a number of $P$. syringae pathovars, further highlighting their mobility (Table 3). Our previous data indicated that PFPs from diverse pathovars could be categorized by the presence of a particular type IV secretion system (type IVA or type IVB) and that certain fitness-enhancing genes were usually associated with plasmids carrying one or the other type IV secretion system (54). The evidence for interplasmid transfer of genes obtained in this study signifies that attempts to reconstruct the evolution of individual PFPs would be difficult.

In summary, our study has demonstrated key tenets in the evolution of the pPT23A plasmid family, namely, that PFPs have been readily transferred among $P$. syringae pathovars and between genomospecies and that individual genes can move from plasmid to plasmid. Because of the importance of horizontal transfer in the evolution of virulence in $P$. syringae, it is likely that PFPs play a critical role in gene acquisition and deployment among strains and pathovars. We are currently pursuing a mechanistic analysis of the molecular evolution of PFPs, with a goal of understanding how these mosaic structures are generated and understanding the selective forces driving maintenance or reorganization of plasmid sequences.

\section{ACKNOWLEDGMENTS}

This work was supported by the following agencies: the United States Department of Agriculture (USDA-NRI 2003-01531 to G.W.S.) and the Michigan Agricultural Experiment Station (Z.M., J.J.S., Y.Z., and G.W.S.), the UK Biotechnology and Biological Sciences Research Council (R.W.J. and D.L.A.), and the Spanish Ministerio de Educación y Ciencia (AGL2004-03143 [J.M.]).

We thank Alan Vivian for useful discussions and Stuart Avery and Diane Butcher for technical support.

\section{REFERENCES}

1. Alarcon-Chaidez, F. J., A. Penaloza-Vazquez, M. Ullrich, and C. L. Bender. 1999. Characterization of plasmids encoding the phytotoxin coronatine in Pseudomonas syringae. Plasmid 42:210-220.

2. Arnold, D. L., R. W. Jackson, and A. Vivian. 2000. Evidence for the mobility of an avirulence gene, avrvPpiA1, between the chromosome and plasmids of races of Pseudomonas syringae pv. pisi. Mol. Plant Pathol. 1:195-199.

3. Austin, S., and K. Nordstrom. 1990. Partition-mediated incompatibility of bacterial plasmids. Cell 60:351-354.

4. Bjorklof, K., E. L. Nurmiaho-Lassila, N. Klinger, K. Haahtela, and M. Romantschuk. 2000. Colonization strategies and conjugal gene transfer of inoculated Pseudomonas syringae on the leaf surface. J. Appl. Microbiol. 89:423-432.

5. Brenner, D. J., and S. Falkow. 1971. Molecular relationships among members of the Enterobacteriaceae. Adv. Genet. 16:81-118.

6. Buell, C. R., V. Joardar, M. Lindeberg, J. Selengut, I. T. Paulsen, M. L. Gwinn, R. J. Dodson, R. T. Deboy, A. S. Durkin, J. F. Kolonay, R. Madupu, S. Daugherty, L. Brinkac, M. J. Beanan, D. H. Haft, W. C. Nelson, T. Davidsen, N. Zafar, L. W. Zhou, J. Liu, Q. P. Yuan, H. Khouri, N. Fedorova, B. Tran, D. Russell, K. Berry, T. Utterback, S. E. Van Aken, T. V. Feldblyum, M. 
D'Ascenzo, W. L. Deng, A. R. Ramos, J. R. Alfano, S. Cartinhour, A. K. Chatterjee, T. P. Delaney, S. G. Lazarowitz, G. B. Martin, D. J. Schneider, X. Y. Tang, C. L. Bender, O. White, C. M. Fraser, and A. Collmer. 2003. The complete genome sequence of the Arabidopsis and tomato pathogen Pseudomonas syringae pv. tomato DC3000. Proc. Natl. Acad. Sci. USA 100:1018110186.

7. Bull, J. J., J. P. Huelsenbeck, C. W. Cunningham, D. L. Swofford, and P. J. Waddell. 1993. Partitioning and combining data in phylogenetic analysis. Syst. Biol. 42:384-397.

8. Cazorla, F. M., E. Arrebola, A. Sesma, A. Perez-Garcia, J. C. Codina, J. Murillo, and A. de Vicente. 2002. Copper resistance in Pseudomonas syringae strains isolated from mango is encoded mainly by plasmids. Phytopathology 92:909-916.

9. Cournoyer, B., J. D. Sharp, A. Astuto, M. J. Gibbon, J. D. Taylor, and A. Vivian. 1995. Molecular characterization of the Pseudomonas syringae pv. pisi plasmid-borne avirulence gene avrPpiB which matches the $R 3$ resistance locus in pea. Mol. Plant-Microbe Interact. 8:700-708.

10. Cuppels, D. A., and T. Ainsworth. 1995. Molecular and physiological characterization of Pseudomonas syringae pv. maculicola strains that produce the phytotoxin coronatine. Appl. Environ. Microbiol. 61:3530-3536.

11. Espinosa-Urgel, M. 2004. Plant-associated Pseudomonas populations: molecular biology, DNA dynamics, and gene transfer. Plasmid 52:139-150.

12. Gardan, L., H. Shafik, S. Belouin, R. Broch, F. Grimont, and P. A. D. Grimont. 1999. DNA relatedness among the pathovars of Pseudomonas syringae and description of Pseudomonas tremae sp. nov. and Pseudomonas cannabina sp. nov. (ex Sutic and Dowson 1959). Int. J. Syst. Bacteriol. 49:469-478.

13. Gibbon, M. J., A. Sesma, A. Canal, J. R. Wood, E. Hidalgo, J. Brown, A Vivian, and J. Murillo. 1999. Replication regions from plant-pathogenic Pseudomonas syringae plasmids are similar to ColE2-related replicons. Microbiology 145:325-334.

14. Glickmann, E., L. Gardan, S. Jacquet, S. Hussain, M. Elasri, A. Petit, and Y. Dessaux. 1998. Auxin production is a common feature of most pathovars of Pseudomonas syringae. Mol. Plant-Microbe Interact. 11:156-162.

15. Jackson, R. W., E. Athanassopoulos, G. Tsiamis, J. W. Mansfield, A. Sesma, D. L. Arnold, M. J. Gibbon, J. Murillo, J. D. Taylor, and A. Vivian. 1999. Identification of a pathogenicity island, which contains genes for virulence and avirulence, on a large native plasmid in the bean pathogen Pseudomonas syringae pathovar phaseolicola. Proc. Natl. Acad. Sci. USA 96:10875-10880.

16. Jackson, R. W., J. W. Mansfield, H. Ammouneh, L. C. Dutton, B. Wharton, A. Ortiz-Barredo, D. L. Arnold, G. Tsiamis, A. Sesma, D. Butcher, J. Boch, Y. J. Kim, G. B. Martin, S. Tegli, J. Murillo, and A. Vivian. 2002. Location and activity of members of a family of virPphA homologues in pathovars of Pseudomonas syringae and P. savastanoi. Mol. Plant Pathol. 3:205-216.

17. Joardar, V., M. Lindeberg, R. W. Jackson, J. Selengut, R. Dodson, L. M. Brinkac, S. C. Daugherty, R. DeBoy, A. S. Durkin, M. G. Giglio, R. Madupu, W. C. Nelson, M. J. Rosovitz, S. Sullivan, J. Crabtree, T. Creasy, T. Davidsen, D. H. Haft, N. Zafar, L. Zhou, R. Halpin, T. Holley, H. Khouri, T. Feldblyum, O. White, C. M. Fraser, A. K. Chatterjee, S. Cartinhour, D. J. Schneider, J. Mansfield, A. Collmer, and C. R. Buell. 2005. Whole-genome sequence analysis of Pseudomonas syringae pv. phaseolicola 1448A reveals divergence among pathovars in genes involved in virulence and transposition. J. Bacteriol. 187:6488-6498.

18. Kado, C. I., and S. T. Liu. 1981. Rapid procedure for detection and isolation of large and small plasmids. J. Bacteriol. 145:1365-1373.

19. Mukhopadhyay, P., M. Mukhopadhyay, and D. Mills. 1990. Construction of a stable shuttle vector for high-frequency transformation in Pseudomonas syringae pv. syringae. J. Bacteriol. 172:477-480.

20. Murillo, J., and N. T. Keen. 1994. Two native plasmids of Pseudomonas syringae pathovar tomato strain PT23 share a large amount of repeated DNA, including replication sequences. Mol. Microbiol. 12:941-950.

21. Novick, R. P. 1987. Plasmid incompatibility. Microbiol. Rev. 51:381-395.

22. Osborn, A. M., F. M. D. Tatley, L. M. Steyn, R. W. Pickup, and J. R. Saunders. 2000. Mosaic plasmids and mosaic replicons: evolutionary lessons from the analysis of genetic diversity in IncFII-related replicons. Microbiology 146:2267-2275.

23. Palleroni, N. J. 1984. Genus I Pseudomonas Migula 1894, p. 141-199. In N. R. Krieg and J. G. Holt (ed.), Bergey's manual of systematic bacteriology. Williams \& Wilkins, Baltimore, MD

24. Piwowarski, J. M., and P. D. Shaw. 1982. Characterization of plasmids from plant pathogenic pseudomonads. Plasmid 7:85-94.

25. Posada, D., and K. A. Crandall. 1998. Modeltest: testing the model of DNA substitution. Bioinformatics 14:817-818.

26. Rohmer, L., S. Kjemtrup, P. Marchesini, and J. L. Dangl. 2003. Nucleotide sequence, functional characterization and evolution of $\mathrm{pFKN}$, a virulence plasmid in Pseudomonas syringae pathovar maculicola. Mol. Microbiol. 47: $1545-1562$.

27. Rossello-Mora, R., and R. Amann. 2001. The species concept for prokaryotes. FEMS Microbiol. Rev. 25:39-67.

28. Rozas, J., and R. Rozas. 1999. DnaSP version 3: an integrated program for molecular population genetics and molecular evolution analysis. Bioinformatics 15:174-175.
29. Saitou, N., and M. Nei. 1987. The neighbor-joining method-a new method for reconstructing phylogenetic trees. Mol. Biol. Evol. 4:406-425.

30. Sarkar, S. F., and D. S. Guttman. 2004. The evolution of the core genome of Pseudomonas syringae, a highly clonal, endemic plant pathogen. Appl. Environ. Microbiol. 70:1999-2012

31. Sawada, H., F. Suzuki, I. Matsuda, and N. Saitou. 1999. Phylogenetic analysis of Pseudomonas syringae pathovars suggests the horizontal gene transfer of $\arg K$ and the evolutionary stability of the hrp gene cluster. J. Mol. Evol. 49:627-644.

32. Sesma, A., G. W. Sundin, and J. Murillo. 1998. Closely related plasmid replicons coexisting in the phytopathogen Pseudomonas syringae show a mosaic organization of the replication region and altered incompatibility behavior. Appl. Environ. Microbiol. 64:3948-3953.

33. Sesma, A., G. W. Sundin, and J. Murillo. 2000. Phylogeny of the replication regions of pPT23A-like plasmids from Pseudomonas syringae. Microbiology 146:2375-2384.

34. Stavrinides, J., and D. S. Guttman. 2004. Nucleotide sequence and evolution of the five-plasmid complement of the phytopathogen Pseudomonas syringae pv. maculicola ES4326. J. Bacteriol. 186:5101-5115.

35. Sundin, G. W., and C. L. Bender. 1993. Ecological and genetic analysis of copper and streptomycin resistance in Pseudomonas syringae pv. syringae. Appl. Environ. Microbiol. 59:1018-1024.

36. Sundin, G. W., and C. L. Bender. 1996. Molecular analysis of closely-related copper- and streptomycin-resistance plasmids in Pseudomonas syringae pv. syringae. Plasmid 35:98-107.

37. Sundin, G. W., D. H. Demezas, and C. L. Bender. 1994. Genetic and plasmid diversity within natural populations of Pseudomonas syringae with various exposures to copper and streptomycin bactericides. Appl. Environ. Microbiol. 60:4421-4431.

38. Sundin, G. W., J. L. Jacobs, and J. Murillo. 2000. Sequence diversity of rulA among natural isolates of Pseudomonas syringae and effect on function of rulABmediated UV radiation tolerance. Appl. Environ. Microbiol. 66:5167-5173.

39. Sundin, G. W., S. P. Kidambi, M. Ullrich, and C. L. Bender. 1996. Resistance to ultraviolet light in Pseudomonas syringae: sequence and functional analysis of the plasmid-encoded rulAB genes. Gene 177:77-81.

40. Sundin, G. W., C. T. Mayfield, Y. F. Zhao, T. S. Gunasekera, G. L. Foster, and M. S. Ullrich. 2004. Complete nucleotide sequence and analysis of pPSR1 (72,601 bp), a pPT23A-family plasmid from Pseudomonas syringae pv. syringae A2. Mol. Gen. Genomics 270:462-475.

41. Sundin, G. W., and J. Murillo. 1999. Functional analysis of the Pseudomonas syringae rulAB determinant in tolerance to ultraviolet B $(290-320 \mathrm{~nm})$ radiation and distribution of rulAB among $P$. syringae pathovars. Environ. Microbiol. 1:75-87.

42. Swofford, D. L. 2000. PAUP*. Phylogenetic analysis using parsimony (*and other methods), version 4. Sinauer Associates, Sunderland, MA

43. Thompson, J. D., D. G. Higgins, and T. J. Gibson. 1994. Clustal-W-improving the sensitivity of progressive multiple sequence alignment through sequence weighting, position-specific gap penalties and weight matrix choice. Nucleic Acids Res. 22:4673-4680.

44. Tsiamis, G., J. W. Mansfield, R. Hockenhull, R. W. Jackson, A. Sesma, E. Athanassopoulos, M. A. Bennett, C. Stevens, A. Vivian, J. D. Taylor, and J. Murillo. 2000. Cultivar-specific avirulence and virulence functions assigned to $a v r P p h F$ in Pseudomonas syringae pv. phaseolicola, the cause of bean halo-blight disease. EMBO J. 19:3204-3214.

45. van Elsas, J. D., S. Turner, and M. J. Bailey. 2003. Horizontal gene transfer in the phytosphere. New Phytol. 157:525-537.

46. Vivian, A., J. Murillo, and R. W. Jackson. 2001. The roles of plasmids in phytopathogenic bacteria: mobile arsenals? Microbiology 147:763-780.

47. Von Bodman, S. B., and P. D. Shaw. 1987. Conservation of plasmids among plant-pathogenic Pseudomonas syringae isolates of diverse origins. Plasmid 17:240-247.

48. Weingart, H., B. Volksch, and M. S. Ullrich. 1999. Comparison of ethylene production by Pseudomonas syringae and Ralstonia solanacearum. Phytopathology 89:360-365.

49. Wiebe, W. L., and R. N. Campbell. 1993. Characterization of Pseudomonassyringae pv maculicola and comparison with $P$-s tomato. Plant Dis. 77:414-419.

50. Wiens, J. J. 1998. Combining data sets with different phylogenetic histories. Syst. Biol. 47:568-581.

51. Yamamoto, S., H. Kasai, D. L. Arnold, R. W. Jackson, A. Vivian, and S. Harayama. 2000. Phylogeny of the genus Pseudomonas: intrageneric structure reconstructed from the nucleotide sequences of $\operatorname{gyr} B$ and $r p o D$ genes. Microbiology 146:2385-2394.

52. Young, J. M., G. S. Saddler, Y. Takikawa, S. H. DeBoer, L. Vauterin, L Gardan, R. I. Gvozdyak, and D. E. Stead. 1996. Names of plant pathogenic bacteria 1864-1995. Rev. Plant Pathol. 75:721-763.

53. Yucel, I., D. Boyd, Q. Debnam, and N. T. Keen. 1994. Two different classes of avrD alleles occur in pathovars of Pseudomonas syringae. Mol. PlantMicrobe Interact. 7:131-139.

54. Zhao, Y., Z. Ma, and G. W. Sundin. 2005. Comparative genomic analysis of the pPT23A plasmid family of Pseudomonas syringae. J. Bacteriol. 187:2113-2126. 